\title{
Genomics relevant to the neuroanaesthesiologist
}

\author{
Vidya Chidambaran
}

\section{INTRODUCTION}

'It is more important to know what sort of person has a disease, than to know what sort of disease a person has'. $\sim$ Hippocrates (circa. 460-370 BC)

The essence of Hippocrates' observation is coming to fruition 25 centuries later ${ }^{[1]}$ in the understanding of genomics to explain inter-individual variability, and in response, application of the knowledge to improve clinical outcomes. Anaesthesia speciality has been the forerunner for many discoveries and applications in genomics from the infant stages of the field, for example, interactions of barbiturate in patients with porphyria (1937),,$^{[2]}$ cholinesterase deficiency leading to succinylcholine-induced prolonged apnoea (1957) ${ }^{[3]}$ and malignant hyperthermia (1962). ${ }^{[4]}$ In the field of neurosurgery, reports of personalised therapy decisions based on genetic, epigenetic and molecular biomarkers have recently emerged - use of candidate molecular markers to complement diagnoses, aid prognosis and allow individualised treatment to patients with glioblastoma multiforme, thereby avoiding unnecessary therapy, reducing toxicity and associated costs. ${ }^{[5]}$ While the decision to operate or not is being aided by genetics, the perioperative period is itself a model of stress and inflammation superimposed on complex disease and is associated with pain and haemodynamic/ metabolic shifts ${ }^{[6]}$ - all these elements have a genetic basis for individual response variability. As can be imagined, surgical trauma triggers an integrated neuroendocrine reaction, and the body mounts a counter-regulatory response. The balance between these pro-inflammatory pathways and the response is an individually determined process and affects patient outcomes. This makes it imperative that personalisation be the backbone of patient management during this period.

Department of Anesthesiology, Division of Pediatrics, Cincinnati Children's Hospital, Cincinnati, OH, USA

\begin{tabular}{|l|l|}
\hline \multicolumn{2}{|c|}{ Access this article online } \\
\hline Quick Response Code: & Website: \\
\hline & www.jnaccjournal.org \\
\cline { 2 - 2 } & \\
\hline & DOI: \\
\hline
\end{tabular}

Moreover, the patient is exposed to multiple drugs in a short course of time perioperatively. We know that drug response variability is a major factor leading to perioperative adverse reactions, and genetic factors contribute to an estimated $50 \%$ of drug response variability. ${ }^{[7]}$ This is because about $59 \%$ of drugs cited in adverse drug reactions are metabolised by at least one enzyme with a variant allele known to cause poor metabolism. ${ }^{\left[{ }^{8,9]}\right.}$ Hence, genomics should play an important role in the practice of anaesthesia today. This is of futuristic importance given projections that by 2020, the number of surgeries will increase by $25 \%$, associated costs by $50 \%$ and likelihood of atherosclerotic-related cardiac, cerebral and renal complications by $100 \% \cdot{ }^{[6,10,11]}$ Personalised medicine may be the key to preventing these predictions from becoming true.

\section{BASICS OF GENOMICS}

The term genetics conjures memories of pea plants and single gene disorders. Genomics refers to all of the genes in the human genome and their interactions with each other, the environment and other cultural and psychosocial factors. The Human Genome Project successfully completed the unravelling of the approximately 3 billion deoxyribonucleic acids (DNAs) base pairs that make up the human genome in April 2003. Before that, we thought there would be about 100,000 genes because there were so many different proteins known. Now, we know that there are about 21,000 genes, many of which can make multiple proteins each. DNA transcription to ribonucleic acid (RNA) and translation to protein indicates that changes in DNA sequences may cause functional or structural changes in proteins. The most common type of allelic variation is single-nucleotide polymorphisms (SNPs) when two alternative bases occur at an appreciable frequency in a population $(>1 \%){ }^{[12]}$ Other genetic variations

This is an open access article distributed under the terms of the Creative Commons Attribution-NonCommercial-ShareAlike 3.0 License, which allows others to remix, tweak, and build upon the work non-commercially, as long as the author is credited and the new creations are licensed under the identical terms.

For reprints contact: reprints@medknow.com

How to cite this article: Chidambaran V. Genomics relevant to the neuroanaesthesiologist. J Neuroanaesthesiol Crit Care 2016;3:44-52. 
are called mutations (incidence $<1 \%$ ) which may be duplications, deletions, insertions, translocation or inversion of DNA segments. However, since more than one codon (triplet of nucleotides) code for the same amino acid, not all mutations cause structural changes in the protein. Another exciting field is of epigenetics, which encompasses non-structural DNA modifications which control gene expression by altering transcription (messenger RNA, microRNA, etc.) via histone modification and changes of DNA methylation. ${ }^{[13]}$ Environmental influences are evident from reports of a high frequency of epigenetic differences between aging monozygotic twins. ${ }^{[14]}$ Besides, proteomics, metabolomics and transcriptomics are evolving areas that are beyond the scope of this report.

\section{PHARMACOGENOMICS RELEVANT TO ANAESTHESIA}

It is important to remember that use of an active drug that is metabolised slowly or a prodrug that is metabolised to its active component excessively or by a person with increased receptor sensitivity may cause toxic effects, while an active drug which is metabolised extensively or by a person with reduced receptor sensitivity, may have a reduced effect. This is because of genetic effects on the pharmacokinetics (PKs) and pharmacodynamics of drugs [Figure 1].

\section{Genomics affecting pharmacokinetics of} anaesthetic drugs

The major groups of hepatic enzymes involved in drug metabolism are the Phase 1 (cytochrome P450 enzymes, cholinesterases) and the Phase 2 enzymes (uridine glucuronosyl transferases [UGTs] and N-acetyl transferases). Drugs metabolised by different enzyme groups are given in Table 1. While numerous genetic effects on anaesthetic exposure have been described, ${ }^{[9,15]}$ some important clinical implications for anaesthesia are described below:

\section{CYP enzymes}

The major CYP450 enzymes of importance to anaesthesia providers are CYP3A4, CYP2D6, CYP2C9 and CYP2C19. Variants of CYP2C9 (*2, *3) have been associated with decreased enzyme activity and increased risk of bleeding from non-steroidal anti-inflammatory drugs, ${ }^{[16]}$ warfarin ${ }^{[17]}$ and ibuprofen. ${ }^{[18]}$ The drug label for celecoxib carries a Food and Drug Administration warning regarding careful use in CYP2C9 poor metabolisers. ${ }^{[19]}$ Combination of $C Y P 3 A 4^{*} 1 B$ and $C Y P 3 A 5^{*} 3$ variants was found to be associated with decreased fentanyl metabolism in fentanyl-related deaths. ${ }^{[20]}$ The presence of an SNP (G681A) of the CYP2C19 gene was found to be associated with impaired metabolism of diazepam in a gene-dosage effect manner (4-fold longer half-life in homozygotes and 2-fold longer half-life in heterozygotes carrying the SNP). ${ }^{[1,22]}$ CYP2B $6 * 6$ variant has been associated with increased risk

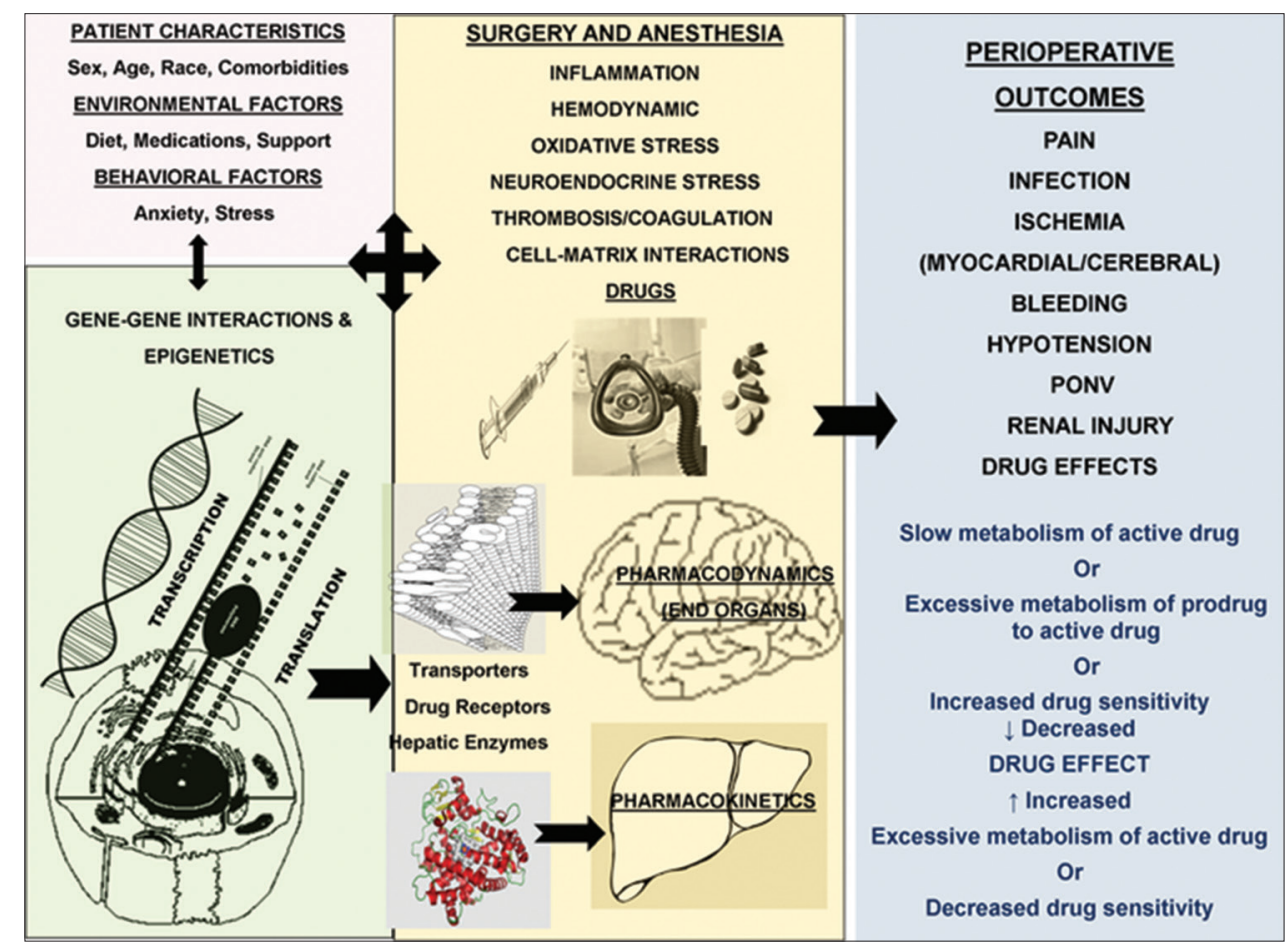

Figure 1: Schematic representation of the effects of an individual's genomics on perioperative outcomes. Gene-gene interactions and environmental influences the person's response to surgical insults and anaesthesia, thereby determining perioperative outcomes. Pharmacogenomic effect on drug responses is also illustrated in simple terms. PONV: Postoperative Nausea and Vomiting 
of death from methadone due to decreased metabolism and QTc prolongation. ${ }^{[23,24]}$ CYP2E1 variant *5 $(-1293 \mathrm{G}>\mathrm{C}$, $-1053 C>T)$ causes increased activity of the enzyme and consequent tendency for halothane hepatitis from exposure to halothane ${ }^{[15]}$ however, may not be an important predictor.

CYP2D6 deserves special mention. Of the federally approved pharmacogenomic information/warnings in the labels of over 100 drugs in the United States, are included analgesics such as codeine and tramadol, which are both metabolised by CYP2D6. ${ }^{[19]}$ Clinical Pharmacogenetics Implementation Consortium guidelines for CYP2D6 and codeine therapy are available for clinical practice. ${ }^{[25]}$ O-demethylation of codeine into morphine by CYP2D6 represents a minor pathway in extensive metabolisers, accounting for $5-10 \%$ of codeine clearance in such individuals but is essential for its opioid activity. PK studies show increased conversion of codeine to morphine in CYP2D 6 ultrarapid metaboliser (UM) versus extensive metabolisers ${ }^{[26]}$ which can result in toxic, systemic

Table 1: Important genes and variants affecting anaesthetic/analgesic drug pharmacokinetics

\begin{tabular}{|c|c|}
\hline Genes & $\begin{array}{l}\text { Perioperative medications whose } \\
\text { pharmacokinetics are affected by } \\
\text { the genetic variants }\end{array}$ \\
\hline CYP2B6 & $\begin{array}{l}\text { Ketamine, propofol, methadone, } \\
\text { buprenorphine, meperidine and tramadol }\end{array}$ \\
\hline CYP2C8 & Diazepam \\
\hline CYP2C9 & $\begin{array}{l}\text { Ibuprofen, diclofenac, naproxen, } \\
\text { indomethacin, warfarin and phenytoin }\end{array}$ \\
\hline CYP2C19 & $\begin{array}{l}\text { Diazepam, midazolam, barbiturates, } \\
\text { tricyclic antidepressants, serotonin reuptake } \\
\text { inhibitors and monoamine oxidase inhibitors }\end{array}$ \\
\hline CYP2D 6 & $\begin{array}{l}\text { Codeine, tramadol, hydrocodone, } \\
\text { dextromethorphan, oxycodone, } \\
\text { ondansetron, dolasetron, palonosetron, } \\
\text { tropisetron and amitryptiline }\end{array}$ \\
\hline CYP2E1 & $\begin{array}{l}\text { Halothane, sevoflurane, desflurane, } \\
\text { isoflurane, acetaminophen and caffeine }\end{array}$ \\
\hline CYP3A4 & $\begin{array}{l}\text { Halothane, ketamine, propofol, midazolam, } \\
\text { morphine, meperidine, fentanyl, sufentanil, } \\
\text { remifentanil, alfentanil, methadone, amide } \\
\text { group (local anaesthetics) and granisetron }\end{array}$ \\
\hline СУР3А5 & $\begin{array}{l}\text { Fentanyl, sufentanil, remifentanil and } \\
\text { alfentanil }\end{array}$ \\
\hline UGT1A1 & Lorazepam, morphine and acetaminophen \\
\hline UGT1A9 & Propofol \\
\hline UGT2B7 & $\begin{array}{l}\text { Morphine, ibuprofen, diclofenac, naproxen } \\
\text { and indomethacin }\end{array}$ \\
\hline$B C h E$ & $\begin{array}{l}\text { Ester group of local anaesthetics, } \\
\text { succinylcholine and mivacurium }\end{array}$ \\
\hline 5,10 MTHFR & Nitrous oxide \\
\hline
\end{tabular}

CYP=Cytochrome P450, UGT=Uridine glucuronosyl transferase, $\mathrm{BChE}=$ Butyrylcholinesterase, MTHFR=Methylenetetrahydrofolate reductase concentrations of morphine ${ }^{[27]}$ even at low codeine doses. The opioids tramadol ${ }^{[28,29]}$ and hydrocodone ${ }^{[30]}$ show similar effects while the data regarding oxycodone are presently conflicting. ${ }^{[31]}$ Aside from genetics, racial differences contribute to morphine clearance variability with higher clearance observed in African Americans. ${ }^{[32]}$ Furthermore, metabolised by CY2D6 are the most commonly used agents for post-operative nausea and vomiting (PONV), the serotonin receptor antagonists (ondansetron, palonosetron and dolasetron) and hence are less effective in UM phenotypes andin UMs. Only granisetron is metabolised by CYP3A4 mainly and may have superior efficacy in CYP2D6 UM patients. ${ }^{[33]}$

\section{Hepatic drug transporters}

Hepatic transporters of morphine (organic cationic transporter 1 [OCT1]) and morphine metabolites (ATP Binding Cassette C3 [ABCC3]) also play a role in morphine PKs. In children undergoing tonsillectomy, the authors found that morphine clearance in homozygotes of loss-of-function OCT1 variants $\left({ }^{*} 2-* 5 /{ }^{*} 2-* 5\right)$ was significantly lower $(20 \%)$ than in wild-type $\left({ }^{*} 1 /{ }^{*} 1\right)$ and heterozygotes $\left({ }^{*} 1 /{ }^{*} 2-{ }^{*} 5\right) \cdot{ }^{[34]}$ In the same population, they also found that children with $A B C C 3-211 C>T$ polymorphism $\mathrm{C} / \mathrm{C}$ genotype had significantly higher levels of morphine-6-glucuronide and morphine-3-glucuronide formation $(\sim 40 \%)$ than $\mathrm{C} / \mathrm{T}+\mathrm{T} / \mathrm{T}$ genotypes. ${ }^{[35]}$ These genotypes were also associated with clinical effects such as morphine-induced respiratory depression (personal communications).

\section{Other pharmacokinetic related genes}

Another historical example is that of decreased pseudocholinesterase activity associated with $>30$ genetic variants leading to prolonged apnoea after use of succinylcholine - the two most common variants are the A variant (209A $>$ G, Asp70Gly) and the K variant (1615G>A, Ala539Thr). ${ }^{[36,37]}$ A transversion of $766 \mathrm{G}>\mathrm{A}$ in the UGT1A9 gene resulting in the substitution of amino acid D256N was found to increase the risk of suffering adverse effects of propofol. ${ }^{[38]}$ Selzer et al. reported the unexpected neurological deterioration of an infant boy after exposure to nitrous oxide twice in a short time. ${ }^{[39]}$ Post-mortem analysis showed 5,10-methylenetetrahydrofolate reductase deficiency in this infant's fibroblasts and a complex combination of mutations in his 5,10-methylenetetrahydrofolate reductase gene including C677T and A1298C SNPs associated with a reduction in the enzyme activity. ${ }^{[0]}$

\section{GENOMICS AND EFFECTS ON ANAESTHETIC PHARMACODYNAMICS}

\section{Anaesthetic effects}

Variations in the gene GABRE, coding for class epsilon of the gamma-aminobutyric acid type A (GABAA) 
receptor (gene map locus Xq28), may explain some of the differential sensitivity to diazepam, barbiturates and propofol [Table 2]. ${ }^{[11,42]}$ Volatile anaesthetics act through a different site on the GABAA receptor - a Korean study found a trend for children with the AA genotype in the GABA $\square 2$ nucleotide position 3145 in intron $A / G$ to have increased incidence of emergence agitation, compared to the non-AA group, after sevoflurane anaesthesia in pre-school-aged children. ${ }^{[43]}$ Human melanocortin-1 receptor $(M C 1 R)$ gene is expressed on the surface of melanocytes and affects melanin biosynthetic pathway and pigment formation. Variants of this gene are linked to red hair in women; Liem et al. found that red hair is a distinct phenotype linked to increased desflurane anaesthetic requirements that can be traced to three particular mutations of the MC1R gene (R151C, R160W and D294H). ${ }^{[44]}$

\section{B-adrenergic receptor $A D R B 2$ and vasopressor requirement}

Blood pressure variability after neuraxial anaesthesia was found to be predicted by variant Arg16Arg (less hypotension) $^{[45]}$ and Glu27 (more hypotension) ${ }^{[46]}$ in two different studies. A detailed review of the $A D R \beta 2$ gene can be found in the overview by Litonjua et al. ${ }^{[47]}$ and its effects in chronic pain have been studied by Diatchenko et al. ${ }^{[48]}$

\section{Risk of perioperative myocardial infarction}

The heritability of myocardial infarction (MI) is striking and well supported by family studies. ${ }^{\left[{ }^{[9]}\right.}$ Common genetic variants on chromosome 9p21 and inflammatory gene polymorphisms ${ }^{[10]}$ (interleukin $6[I L-6-572 \mathrm{G}>\mathrm{C}]$ ) and two adhesion molecules, intercellular adhesion molecule-1 (ICAM1 Lys469Glu) and E-selectin (SELE 98G $>$ T), were found to be associated with perioperative myocardial injury and mortality after coronary artery bypass ${ }^{[50-52]}$ Genetic risk factors have also been described for post-operative arrhythmias (IL-6174G/C). ${ }^{[53]}$ Readers are referred to an excellent review on perioperative genomics by Schwinn and Podgoreanu ${ }^{[54]}$ for further elaboration.

\section{Risk of perioperative cerebral ischaemia and cognitive dysfunction}

Apolipoprotein E (APOE) is the gene responsible for the production of APOE and has been widely studied in relation to cerebral ischaemia, traumatic brain injury (TBI) and Alzheimer's disease. In humans, there are three common isoforms of APOE, encoded by the alleles $\varepsilon 2$, $\varepsilon 3$ and $\varepsilon 4$. Clinical and experimental studies suggest that APOE $\varepsilon 4$ is associated with an unfavourable functional outcome after TBI. ${ }^{[55-57]}$ The inheritance of APOE $\varepsilon 4$ allele has been mentioned as a risk factor for Alzheimer's disease after TBI although this has not yet been conclusively shown ${ }^{[58]}$ These effects might be due to differential cerebral
Table 2: Anaesthesia relevant genes affecting perioperative outcomes

\begin{tabular}{|c|c|}
\hline Perioperative outcome & Genes implicated \\
\hline Anaesthetic requirement & $\begin{array}{l}\text { Gamma butyric acid receptor } \\
\text { gene } G A B R E, G A B A \gamma 2 ; M C 1 R\end{array}$ \\
\hline Vasopressor requirement & $A D R \beta 2$ \\
\hline $\begin{array}{l}\text { Perioperative myocardial } \\
\text { injury/dysfunction }\end{array}$ & $\begin{array}{l}\text { IL-6, IL-10, ICAM-1, SELE, } \\
\text { factor V; GNB3; GP1BA }\end{array}$ \\
\hline $\begin{array}{l}\text { Post-operative } \\
\text { arrhythmias }\end{array}$ & IL-6, TNF-a, RANTES \\
\hline $\begin{array}{l}\text { Perioperative cerebral } \\
\text { effects }\end{array}$ & $\begin{array}{l}\text { APOE, CRP, IL-6, platelet } \\
\text { glycoprotein IIIA PIA2 }\end{array}$ \\
\hline PONV & $\begin{array}{l}\text { DRD2, M3 muscarinic } \\
\text { acetylcholine receptor } \\
(C H R M 3), F A A H\end{array}$ \\
\hline Perioperative bleeding & $\begin{array}{l}\text { GPIaIIa, GPIb alpha, tissue } \\
\text { factor, prothrombin, tissue factor } \\
\text { pathway inhibitor, ACE, PAI-1 }\end{array}$ \\
\hline Renal injury & $\begin{array}{l}\text { Angiotensinogen, } I L-6, A P O E \text {, } \\
\text { angiotensin receptor } 1 \text {, eNOS }\end{array}$ \\
\hline Sepsis & $\begin{array}{l}I L-1 \text {, beta } I L-1 B, T N F, C D 3 d \\
\text { molecule, delta (CD3-TCR } \\
\text { complex) CD3D, PRF1 }\end{array}$ \\
\hline Graft rejection & $\begin{array}{l}\text { TNFa, IL-10, IL-1B, ICAM-1, } \\
I L-1 R N\end{array}$ \\
\hline Pain & COMT \\
\hline Opioid action/interaction & ABCB1 OPRM1 gene FAAH \\
\hline \multicolumn{2}{|c|}{$\begin{array}{l}\text { MC1R=Melanocortin-1 receptor, ADR } 32=\text { Beta-2 adrenergic receptor, } \\
\text { IL=Interleukin, ICAM- } 1=\text { =ntercellular adhesion molecule-1, SELE=E-selectin, } \\
\text { GNB3=G-protein-3 subunit, GP1BA=Glycoprotein Ib alpha, TNF- } \alpha=\text { =Tumour } \\
\text { necrosis factor alpha, RANTES=Regulated upon activation normally } \\
\text { T-expressed and secreted, APOE=Apolipoprotein E, CRP=C-reactive protein, } \\
\text { DRD2=Dopamine receptor D2, CHRM3=Cholinergic receptor, muscarinic } 3 \text {, } \\
\text { FAAH=Fatty acid amide hydroxylase, ACE=Angiotensin converting enzyme, } \\
\text { PAI-1=Plasminogen activator inhibitor-1, eNOS=Endothelial nitric oxide } \\
\text { synthase, PRF1=Perforin } 1 \text { (pore forming protein), IL-1RN=Interleukin-1 receptor } \\
\text { antagonist, TCR=T-cell receptor, COMT: Cathechol-o-methyltransferase, } \\
\text { ABCB1=ATP-binding cassette B1, OPRM1= } 11 \text { opioid receptor, FAAH=Fatty } \\
\text { acid amide hydroxylase, PONV=Post-operative nausea and vomiting, } \\
\text { GABRE=Gamma-aminobutyric acid A receptors }\end{array}$} \\
\hline
\end{tabular}

blood flow responses in this genotype. Kofke et al. ${ }^{[59]}$ found that subjects with Apoe4 genotype showed relative activation of the hippocampus and amygdala in response to increasing doses of remifentanil- they suggest that this differential activation may be important in perioperative cerebral ischaemia involved in cognitive dysfunction and a role for endogenous opiates in Alzheimer's. Several recent trials have highlighted how genetic milieu either increases the pre-disposition for neurologic injury or impairs the ability to recover once that injury has occurred. ${ }^{[60,61]}$ In a large sample $(n=2104)$, Grocott $e t$ al. studied association of 26 SNPs and their interactions for association with post-cardiac surgery stroke. Interaction of inflammatory markers C-reactive protein (CRP) and IL-6 SNPs was associated with a significantly increased risk of stroke, ${ }^{[62]}$ with an incidence of $3.09 \%$ compared with an incidence 
of $0.95 \%$ in a population without the risk genotypes. This study highlighted a potential mechanistic pathway for perioperative stroke, inflammatory superseded thrombosis-related genes and was similar to that found in risk of MI after cardiac surgery. ${ }^{[62]}$ Genetic makeup and gene expression have been described to contribute to a person's vulnerability to stroke. Numerous genes were implicated; they were induced 1.6-6.8-fold in stroke patients and correctly classified $11 / 15$ patients at $2.4 \mathrm{~h}$, $14 / 15$ patients at $5 \mathrm{~h}$ and $15 / 15$ patients at $24 \mathrm{~h}$ after stroke. ${ }^{[63,64]}$

\section{Neuroprotective genes}

Mathew et al. outlined association of P-selectin (SELP) 1087G/A, CRP1059G/C and platelet glycoprotein IIIA PIA2 polymorphisms with a reduction in overall cognitive deficits after surgery supporting the biologic plausibility of reduced inflammation and platelet activation leading to protective outcomes. ${ }^{[65,66]}$ Besides, certain neuroprotective genes such as erythropoietin, tumour growth factor and hypoxia inducible factor- 1 are induced by pre-ischemic stress. This raises exciting prospects for use of viral vectors to potentially deliver neuroprotective genes at high levels to prevent cell death. ${ }^{[67]}$

\section{Post-operative nausea and vomiting}

In a recent genome-wide association study on motion sickness in 80,494 individuals from the 23andMe database, the authors concluded that 35 SNPs involved in balance, glucose homeostasis and other nervous system roles played an important part in motion sickness and likely, PONV too. ${ }^{[68]}$ Besides, correlations have been reported between A2A2 alleles at Dopamine D2 receptor (Taq1A SNP) ${ }^{[69,70]}$ as well as rs2165870 SNP in the promoter region of the $\mathrm{M} 3$ muscarinic acetylcholine receptor (CHRM3) gene with PONV. ${ }^{[71]}$

\section{Perioperative bleeding}

Post-operative bleeding after cardiac surgery was found to be associated with SNPs of coagulation proteins and platelet glycoproteins (GPIaIIa $-52 \mathrm{C}>\mathrm{T}$ and $807 \mathrm{C}>\mathrm{T}$, $\mathrm{GPIb}$ alpha $524 \mathrm{C}>\mathrm{T}$, tissue factor $-603 \mathrm{~A}>\mathrm{G}$, prothrombin 20210G $>$ A, tissue factor pathway inhibitor-399C $>$ T and angiotensin converting enzyme deletion/insertion). ${ }^{[72]}$ As a corollary, a study evaluating efficacy of tranexamic acid (TXA) in reducing bleeding after cardiac surgery in different genotypes found that 5G/5G homozygotes of the PAI-1 gene who did not receive TXA had significantly greater post-operative bleeding after cardiac surgery than patients with other genotypes. They also had greater blood-sparing benefit from TXA than the $4 \mathrm{G} / 4 \mathrm{G}$ homozygotes. ${ }^{[73]}$

\section{Other perioperative complications}

Studies have shown associations between specific genetic variants and specific post-operative complications; ${ }^{[74]}$ including renal compromise, ${ }^{[75]}$ protection against sepsis (Apo\&3), ${ }^{[76]}$ sepsis, ${ }^{[77]}$ inflammatory response and graft rejection after heart and lung transplants. ${ }^{[78]}$

\section{GENOMICS OF PAIN AND OPIOIDS}

\section{Pain perception}

Catechol-o-methyltransferase (COMT) is the main enzyme responsible for inactivation of catecholamines including dopamine, epinephrine and norepinephrine. Genotypes of the COMT SNPs rs6269, rs4633, rs4818 and rs4680 were grouped into functional haplotypes associated with low-, average- and high-pain sensitivity in adults with non-surgical pain. ${ }^{[79-81]}$ The SNP rs4680 is a common polymorphism of the COMT gene on chromosome 22 q11 coded by $472 \mathrm{G}>\mathrm{A}$, which causes the substitution of valine by methionine at amino acid position 158 (Val158Met). This results in a decrease in COMT enzyme activity which leads to high pain sensitivity. In a study of 149 children undergoing tonsillectomy, minor allele carriers of COMTSNPs were approximately 3-times more likely to require analgesic interventions than homozygotes of major alleles $(P$ value range: $0.0031-0.0127$; odds ratio range: $2.6-3.1){ }^{[82]}$

\section{Opioid transport across the blood-brain}

\section{barrier}

The concentration of morphine in brain is influenced by a P-glycoprotein transporter, $A B C B 1$ at the blood-brain barrier. A polymorphism of $A B C B 1, \mathrm{c} .3435 \mathrm{C}>\mathrm{T}$, has been linked with morphine's blood-brain barrier transport activity in adults and the homozygous TT genotype was associated with higher maximum cerebrospinal fluid concentrations of morphine than other genotypes. ${ }^{[83]}$ Previously, $A B C B 1$ polymorphisms, c. $3435 \mathrm{C}>\mathrm{T}$ and 1236TT were associated with respiratory depression in Korean adults receiving fentany ${ }^{[84]}$ and Turkish adults receiving spinal anaesthesia and intravenous fentanyl. ${ }^{[85]}$ The homozygous diplotype (GG-CC at c. $2677 \mathrm{G}>\mathrm{T} / \mathrm{A}$ and c. $3435 \mathrm{C}>\mathrm{T}$ ) was shown to have borderline association with morphine-induced PONV. ${ }^{[86]}$ Children with GG and GA genotypes of $A B C B 1$ polymorphism rs9282564 had higher risks of respiratory depression resulting in prolonged hospital stays after tonsillectomy. ${ }^{[87]}$

\section{Opioid receptor}

Opioid receptor $\mu 1$ gene (OPRM1) that codes for this receptor has a functionally significant and common variant called A118G (rs1799971). This SNP causes substitution of an adenine (A) with a guanine $(\mathrm{G})$ at base 118, which in turn causes the amino acid exchange at position 40 of the $\mu$-opioid receptor protein from asparagine to aspartic acid (N40D), leading to the loss of a $\mathrm{N}$-glycosylation site in the extracellular region of 
the receptor. ${ }^{[88]}$ Various studies show that individuals with GG genotype require more opioids $24 \mathrm{~h}$ following surgery. ${ }^{[89-92]}$ In adolescents undergoing spine fusion, the authors found that the risk of respiratory depression from morphine in patients with AA genotype was significantly higher (odds ratio 5.6, 95\% confidence interval: $1.4-37.2, P=0.030) .{ }^{[93]}$ However, the debate is far from over as a meta-analysis by Walter and Lötsch shows. ${ }^{[94]}$

\section{Opioid-cannabinoid system interactions}

Fatty acid amide hydroxylase (FAAH), opioid and cannabinoid systems reciprocally and synergistically modulate functions at multiple levels. FAAH codes for an enzyme that hydrolyses anandamide, the 'bliss' molecule. Hence, FAAH inhibition increases the bioavailability of anandamide and thereby enhances analgesia; this offers a potential therapeutic target for treating pain and has shown promising potential. ${ }^{[95,96]}$ Five specific FAAH SNPs including a missense variant (rs324420) were found to also be associated with more than 2-fold increased risk for refractory PONV in children undergoing tonsillectomy, ${ }^{[97]}$ which shows potentiation of other opioid effects.

\section{CONCLUSION AND FUTURE PERSPECTIVES}

The promise and potential for genomics in perioperative medicine is evident from the rapidly increasing plethora of studies showing association of genetic variants with perioperative outcomes and pain. Although many studies deal with cardiac surgery and pain, the results are extendable to neuroanaesthesia. From a translational perspective, these findings are expected to allow prospective risk assessment incorporating genomic profiling of markers important in inflammatory, bleeding, thrombotic, vascular and neurologic responses to perioperative stress; Implications range from individualised a priori pre-operative testing and physiological optimisation, to perioperative decision-making, options of monitoring approaches and critical care resource utilisation. Examples of translational potential are the genomic prescribing system proposed by Ratain to guide therapy, ${ }^{[98]}$ the genotype-based dosing of opioids based on OPRM1, COMT and MC1R proposed by Lötsch and Geisslinger ${ }^{[99,100]}$ and genetic risk signatures for opioid-induced respiratory depression reported by Biesiada et al..$^{[101]}$ At present, commercial gene-based assays are available to allow providers to make individualised decisions in prescribing drugs such as psychotropics and analgesics. The Electronic Medical Records and Genomics Network, which was announced in September 2007, is a National Institutes of Health organised and funded consortium of US medical research comprising nine institutions with unique and valuable pioneer experience using a variety of commercial and home-grown electronic health record (EHR). The challenges and solutions for integrating genomic data into the EHR, creation of integrated genomic decision support and the human and electronic processes including standards required for such successful integration are still a work in progress. ${ }^{[102,103]}$

Technological advances in sequencing and plunging costs are not formidable barriers anymore for clinical implementation ${ }^{[104]}$ in developed countries, although limited by availability of testing facilities. Key factors that still stand in the path of clinical implementation are the difficulties encountered in reliable interpretation of the complex genome-wide data, difficulty in defining reliable phenotypes and questionable generalisation of the findings found in extreme phenotypes, to the general population. The other hindrance remains the lack of awareness and education among providers regarding the advances made in this field and their impact on anaesthetic management. Various human disease variant databases such as the Human Gene Mutation Database, ${ }^{[105]}$ the hand-curated databases ClinVar and MutaDatabase, ${ }^{[106]}$ as well as pharmacogenomics databases (www.pharmgkb.org) are available at the click of a mouse nowadays. Interpretation of genetic findings related to variants not previously associated with human pathology or for which there is limited biological insight (for example, model organisms and biochemical studies) is less straightforward and may rely on in silico prediction algorithms (such as PolyPhen, VAAST and ESEfinder) ${ }^{[107,108]}$ which can easily be fallible. ${ }^{[109]}$ Some other resources are the Encyclopaedia of DNA Elements (www.encodeproject.org) data, that is, an online database of functional elements and the Genotype-Tissue Expression project which aims to provide to the scientific community a resource with which to study human gene expression and regulation and its relationship to genetic variation (www.gtexportal.org).

A strong need remains for prospective, well-powered genetic studies in highly phenotyped surgical populations, which mandate the development of multi-institutional collaborations and multidimensional perioperative databases and establishing perioperative research consortia and standardised protocols for specimen collection, processing, phenotype definition and interpretation. Legal and ethical concerns need to be addressed as well as cost-effectiveness evaluated. Despite all the work that still lies ahead, it is unthinkable at this stage that perioperative approaches remain a random generalised test and try approach, instead of being an individualised patient-specific exercise. Herein lays the realisation of Hippocrates' vision of individualised medicine. 
Financial support and sponsorship Nil.

\section{Conflicts of interest}

There are no conflicts of interest.

\section{REFERENCES}

1. Sykiotis GP, Kalliolias GD, Papavassiliou AG. Pharmacogenetic principles in the Hippocratic writings. J Clin Pharmacol 2005;45:1218-20.

2. Waldenstrom J. Studien über porphyrie. Acta Med Scand 1937; Suppl 82:3.

3. Kalow W, Genest K. A method for the detection of atypical forms of human serum cholinesterase; determination of dibucaine numbers. Can J Biochem Physiol 1957;35:339-46.

4. Vogel F, Gotze W. Familial studies on genetics of the normal electroencephalogram. Dtsch Z Nervenheilkd 1959; 178:668-700.

5. Nicolaidis S. Personalized medicine in neurosurgery. Metabolism 2013;62 Suppl 1:S45-8.

6. Turer AT, Schwinn DA. Understanding the transition to acute illness: the promise of perioperative genomics. J Cardiovasc Transl Res 2008;1:171-3.

7. Classen DC, Pestotnik SL, Evans RS, Lloyd JF, Burke JP. Adverse drug events in hospitalized patients. Excess length of stay, extra costs, and attributable mortality. JAMA 1997;277:301-6.

8. Phillips KA, Veenstra DL, Oren E, Lee JK, Sadee W. Potential role of pharmacogenomics in reducing adverse drug reactions: A systematic review. JAMA 2001;286:2270-9.

9. Chidambaran V, Ngamprasertwong P, Vinks AA, Sadhasivam S. Pharmacogenetics and anesthetic drugs. Curr Clin Pharmacol 2012;7:78-101.

10. Podgoreanu MV, White WD, Morris RW, Mathew JP, Stafford-Smith $\mathrm{M}$, Welsby $\mathrm{IJ}$, et al. Inflammatory gene polymorphisms and risk of postoperative myocardial infarction after cardiac surgery. Circulation 2006;114 1 Suppl: I275-81.

11. Mangano DT. Perioperative medicine: NHLBI working group deliberations and recommendations. J Cardiothorac Vasc Anesth 2004;18:1-6.

12. Sachidanandam R, Weissman D, Schmidt SC, Kakol JM, Stein LD, Marth G, et al. A map of human genome sequence variation containing 1.42 million single nucleotide polymorphisms. Nature 2001;409:928-33.

13. Egger G, Liang G, Aparicio A, Jones PA. Epigenetics in human disease and prospects for epigenetic therapy. Nature 2004;429:457-63.

14. Fraga MF, Ballestar E, Paz MF, Ropero S, Setien F, Ballestar ML, et al. Epigenetic differences arise during the lifetime of monozygotic twins. Proc Natl Acad Sci U S A 2005;102:10604-9.

15. Palmer SN, Giesecke NM, Body SC, Shernan SK, Fox AA, Collard CD. Pharmacogenetics of anesthetic and analgesic agents. Anesthesiology 2005;102:663-71.

16. Agúndez JA, García-Martín E, Martínez C. Genetically based impairment in CYP2C8- and CYP2C9-dependent NSAID metabolism as a risk factor for gastrointestinal bleeding: Is a combination of pharmacogenomics and metabolomics required to improve personalized medicine? Expert Opin Drug Metab Toxicol 2009;5:607-20.

17. Higashi MK, Veenstra DL, Kondo LM, Wittkowsky AK, Srinouanprachanh SL, Farin FM, et al. Association between CYP2C9 genetic variants and anticoagulation-related outcomes during warfarin therapy. JAMA 2002;287:1690-8.

18. López-Rodríguez R, Novalbos J, Gallego-Sandín S, Román-Martínez M, Torrado J, Gisbert JP, et al. Influence of
CYP2C8 and CYP2C9 polymorphisms on pharmacokinetic and pharmacodynamic parameters of racemic and enantiomeric forms of ibuprofen in healthy volunteers. Pharmacol Res 2008;58:77-84.

19. U.S. Food and Drug Administration. Table on Pharmacogenomic Biomarkers in Drug Labels.

20. Jin $M$, Gock SB, Jannetto PJ, Jentzen JM, Wong SH. Pharmacogenomics as molecular autopsy for forensic toxicology: Genotyping cytochrome P450 3A4*1B and 3A5\%3 for 25 fentanyl cases. J Anal Toxicol 2005;29:590-8.

21. Inomata $S$, Nagashima $A$, Itagaki $F$, Homma $M$, Nishimura M, Osaka Y, et al. CYP2C19 genotype affects diazepam pharmacokinetics and emergence from general anesthesia. Clin Pharmacol Ther 2005;78:647-55.

22. Qin XP, Xie HG, Wang W, He N, Huang SL, Xu ZH, et al. Effect of the gene dosage of CgammaP2C19 on diazepam metabolism in Chinese subjects. Clin Pharmacol Ther 1999;66:642-6.

23. Eap CB, Crettol S, Rougier JS, Schläpfer J, Sintra Grilo L, Déglon JJ, et al. Stereoselective block of hERG channel by (S)-methadone and QT interval prolongation in CYP2B6 slow metabolizers. Clin Pharmacol Ther 2007;81:719-28.

24. Bunten H, Liang WJ, Pounder DJ, Seneviratne C, Osselton D. OPRM1 and CYP2B6 gene variants as risk factors in methadone-related deaths. Clin Pharmacol Ther 2010;88:383-9.

25. Crews KR, Gaedigk A, Dunnenberger HM, Leeder JS, Klein TE, Caudle KE, et al. Clinical pharmacogenetics implementation consortium guidelines for cytochrome P450 2D6 genotype and codeine therapy: 2014 update. Clin Pharmacol Ther 2014;95:376-82.

26. Kirchheiner J, Schmidt H, Tzvetkov M, Keulen JT, Lötsch J, Roots I, et al. Pharmacokinetics of codeine and its metabolite morphine in ultra-rapid metabolizers due to CYP2D6 duplication. Pharmacogenomics J 2007;7:257-65.

27. Gasche Y, Daali Y, Fathi M, Chiappe A, Cottini S, Dayer P, et al. Codeine intoxication associated with ultrarapid CYP2D6 metabolism. N Engl J Med 2004;351:2827-31.

28. Stamer UM, Lehnen K, Höthker F, Bayerer B, Wolf S, Hoeft A et al. Impact of CYP2D6 genotype on postoperative tramadol analgesia. Pain 2003;105:231-8.

29. Wang G, Zhang H, He F, Fang X. Effect of the CYP2D6*10 C188T polymorphism on postoperative tramadol analgesia in a Chinese population. Eur J Clin Pharmacol 2006;62:927-31.

30. Susce MT, Murray-Carmichael E, de Leon J. Response to hydrocodone, codeine and oxycodone in a CYP2D6 poor metabolizer. Prog Neuropsychopharmacol Biol Psychiatry 2006;30:1356-8.

31. Zwisler ST, Enggaard TP, Mikkelsen S, Brosen $\mathrm{K}$, Sindrup SH. Impact of the CYP2D6 genotype on post-operative intravenous oxycodone analgesia. Acta Anaesthesiol Scand 2010;54:232-40.

32. Sadhasivam S, Krekels EH, Chidambaran V, Esslinger HR, Ngamprasertwong $\mathrm{P}$, Zhang $\mathrm{K}$, et al. Morphine clearance in children: Does race or genetics matter? J Opioid Manag 2012;8:217-26.

33. Janicki PK. Cytochrome P450 2D6 metabolism and 5-hydroxytryptamine type 3 receptor antagonists for postoperative nausea and vomiting. Med Sci Monit 2005; 11:RA322-8.

34. Fukuda T, Chidambaran V, Mizuno T, Venkatasubramanian R, Ngamprasertwong P, Olbrecht V, et al. OCT1 genetic variants influence the pharmacokinetics of morphine in children. Pharmacogenomics 2013;14:1141-51.

35. Venkatasubramanian R, Fukuda $T$, Niu J, Mizuno $T$, Chidambaran V, Vinks AA, et al. ABCC3 and OCT1 genotypes influence pharmacokinetics of morphine in children. Pharmacogenomics 2014;15:1297-309.

36. Calvert J, Lehmann H, Silk E, Slack WK. Prolonged apnoea 
after suxamethonium; a case study of pseudocholinesterase. Lancet 1954;267:354-6.

37. Lando G, Mosca A, Bonora R, Azzario F, Penco S, Marocchi $A$, et al. Frequency of butyrylcholinesterase gene mutations in individuals with abnormal inhibition numbers: An Italian-population study. Pharmacogenetics 2003;13:265-70.

38. Takahashi H, Maruo Y, Mori A, Iwai M, Sato H, Takeuchi Y. Effect of D256N and Y483D on propofol glucuronidation by human uridine 5'-diphosphate glucuronosyltransferase (UGT1A9). Basic Clin Pharmacol Toxicol 2008;103:131-6.

39. Selzer RR, Rosenblatt DS, Laxova R, Hogan K. Adverse effect of nitrous oxide in a child with 5,10-methylenetetrahydrofolate reductase deficiency. N Engl J Med 2003;349:45-50.

40. Erbe RW, Salis RJ. Severe methylenetetrahydrofolate reductase deficiency, methionine synthase, and nitrous oxide - A cautionary tale. N Engl J Med 2003;349:5-6.

41. Wilke K, Gaul R, Klauck SM, Poustka A. A gene in human chromosome band Xq28 (GABRE) defines a putative new subunit class of the GABAA neurotransmitter receptor. Genomics 1997;45:1-10.

42. Buggy DJ, Nicol B, Rowbotham DJ, Lambert DG. Effects of intravenous anesthetic agents on glutamate release: A role for GABAA receptor-mediated inhibition. Anesthesiology 2000;92:1067-73.

43. Park CS, Park HJ, Kim KN, et al. The influence of GABAA $\gamma 2$ genetic polymorphism on the emergence agitation induced by sevoflurane. Korean J Anesthesiol 2008;55:139-44.

44. Liem EB, Lin CM, Suleman MI, Doufas AG, Gregg RG, Veauthier JM, et al. Anesthetic requirement is increased in redheads. Anesthesiology 2004;101:279-83.

45. Magalhães E, Gomes MD, Barra GB, Govêia CS, Ladeira LC. Evaluation of the influence of the codon 16 polymorphism of the Beta-2 adrenergic receptor gene on the incidence of arterial hypotension and ephedrine use in pregnant patients submitted to subarachnoid anesthesia. Rev Bras Anestesiol 2010;60:228-36.

46. Frey UH, Karlik J, Herbstreit F, Peters J. ß2-Adrenoceptor gene variants affect vasopressor requirements in patients after thoracic epidural anaesthesia. Br J Anaesth 2014;112:477-84.

47. Litonjua AA, Gong L, Duan QL, Shin J, Moore MJ, Weiss ST, et al. Very important pharmacogene summary ADRB2. Pharmacogenet Genomics 2010;20:64-9.

48. Diatchenko L, Anderson AD, Slade GD, Fillingim RB, Shabalina SA, Higgins TJ, et al. Three major haplotypes of the beta2 adrenergic receptor define psychological profile, blood pressure, and the risk for development of a common musculoskeletal pain disorder. Am J Med Genet B Neuropsychiatr Genet 2006;141B: 449-62.

49. Samani NJ, Erdmann J, Hall AS, Hengstenberg C, Mangino M, Mayer B, et al. Genomewide association analysis of coronary artery disease. N Engl J Med 2007;357:443-53.

50. Myocardial Infarction Genetics Consortium, Kathiresan S, Voight BF, Purcell S, Musunuru K,Ardissino D, etal.Genome-wide association of early-onset myocardial infarction with single nucleotide polymorphisms and copy number variants. Nat Genet 2009;41:334-41.

51. Liu KY, Muehlschlegel JD, Perry TE, Fox AA, Collard CD, Body SC, et al. Common genetic variants on chromosome 9 p21 predict perioperative myocardial injury after coronary artery bypass graft surgery. J Thorac Cardiovasc Surg 2010;139:483-8, 488.e1-2.

52. Muehlschlegel JD, Liu KY, Perry TE, Fox AA, Collard CD, Shernan SK, et al. Chromosome 9p21 variant predicts mortality after coronary artery bypass graft surgery. Circulation 2010;122 11 Suppl: S60-5.

53. Gaudino M, Andreotti F, Zamparelli R, Di Castelnuovo A, NassoG,BurzottaF, etal.The-174G/Cinterleukin-6polymorphism influences postoperative interleukin-6 levels and postoperative atrial fibrillation. Is atrial fibrillation an inflammatory complication? Circulation 2003;108 Suppl 1:II195-9.

54. Schwinn DA, Podgoreanu M. Pharmacogenomics and end-organ susceptibility to injury in the perioperative period. Best Pract Res Clin Anaesthesiol 2008;22:23-37.

55. Friedman G, Froom P, Sazbon L, Grinblatt I, Shochina M, Tsenter J, et al. Apolipoprotein E-epsilon4 genotype predicts a poor outcome in survivors of traumatic brain injury. Neurology 1999;52:244-8.

56. Teasdale GM, Nicoll JA, Murray G, Fiddes M. Association of apolipoprotein E polymorphism with outcome after head injury. Lancet 1997;350:1069-71.

57. Ariza M, Pueyo R, Matarín Mdel M, Junqué C, Mataró M, Clemente I, et al. Influence of APOE polymorphism on cognitive and behavioural outcome in moderate and severe traumatic brain injury. J Neurol Neurosurg Psychiatry 2006;77:1191-3.

58. Millar K, Nicoll JA, Thornhill S, Murray GD, Teasdale GM. Long term neuropsychological outcome after head injury: Relation to APOE genotype. J Neurol Neurosurg Psychiatry 2003; 74:1047-52.

59. Kofke WA, Blissitt PA, Rao H, Wang J, Addya K, Detre J. Remifentanil-induced cerebral blood flow effects in normal humans: Dose and ApoE genotype. Anesth Analg 2007;105:167-75.

60. Grocott HP. Perioperative genomics and neurologic outcome: We can't change who we are. Can J Anaesth 2009;56:562-6.

61. Gaynor JW, Gerdes M, Zackai EH, Bernbaum J, Wernovsky G, Clancy RR, et al. Apolipoprotein E genotype and neurodevelopmental sequelae of infant cardiac surgery. J Thorac Cardiovasc Surg 2003;126:1736-45.

62. Grocott HP, White WD, Morris RW, Podgoreanu MV, Mathew JP, Nielsen DM, et al. Genetic polymorphisms and the risk of stroke after cardiac surgery. Stroke 2005;36:1854-8.

63. Sharp FR, Xu H, Lit L, Walker W, Pinter J, Apperson M, et al. Genomic profiles of stroke in blood. Stroke 2007;38 2 Suppl: 691-3.

64. Tang Y, Xu H, Du X, Lit L, Walker W, Lu A, et al. Gene expression in blood changes rapidly in neutrophils and monocytes after ischemic stroke in humans: A microarray study. J Cereb Blood Flow Metab 2006;26:1089-102.

65. Mathew JP, Podgoreanu MV, Grocott HP, White WD, Morris RW, Stafford-Smith M, et al. Genetic variants in P-selectin and C-reactive protein influence susceptibility to cognitive decline after cardiac surgery. J Am Coll Cardiol 2007;49:1934-42.

66. Mathew JP, Rinder CS, Howe JG, Fontes M, Crouch J, Newman MF, et al. Platelet PIA2 polymorphism enhances risk of neurocognitive decline after cardiopulmonary bypass. Multicenter Study of Perioperative Ischemia (McSPI) Research Group. Ann Thorac Surg 2001;71:663-6.

67. Yenari MA, Dumas TC, Sapolsky RM, Steinberg GK. Gene therapy for treatment of cerebral ischemia using defective herpes simplex viral vectors. Ann N Y Acad Sci 2001;939:340-57.

68. Hromatka BS, Tung JY, Kiefer AK, Do CB, Hinds DA, Eriksson N. Genetic variants associated with motion sickness point to roles for inner ear development, neurological processes and glucose homeostasis. Hum Mol Genet 2015;24:2700-8.

69. Nakagawa M, Kuri M, Kambara N, Tanigami H, Tanaka H, Kishi Y, et al. Dopamine D2 receptor Taq IA polymorphism is associated with postoperative nausea and vomiting. J Anesth 2008;22:397-403.

70. Ribeiro-Dasilva. The dopamine receptor 2 (DRD2) gene is associated with opioid-induced nausea and emesis. J Pain 2009; 10:S29.

71. Janicki PK, Vealey R, Liu J, Escajeda J, Postula M, Welker K. Genome-wide Association study using pooled DNA to identify 
candidate markers mediating susceptibility to postoperative nausea and vomiting. Anesthesiology 2011;115:54-64.

72. Welsby IJ, Podgoreanu MV, Phillips-Bute B, MathewJP, Smith PK, Newman MF, et al. Genetic factors contribute to bleeding after cardiac surgery. J Thromb Haemost 2005;3:1206-12.

73. Sirgo G, Morales P, Rello J. PAI-1 gene: Pharmacogenetic association of $4 \mathrm{G} / 4 \mathrm{G}$ genotype with bleeding after cardiac surgery - Pilot study. Eur J Anaesthesiol 2009;26:404-11.

74. Ausman JI. Perioperative genomics. Surg Neurol 2006;65:422.

75. Stafford-Smith M, Podgoreanu M, Swaminathan M, Phillips-Bute B, Mathew JP, Hauser EH, et al. Association of genetic polymorphisms with risk of renal injury after coronary bypass graft surgery. Am J Kidney Dis 2005;45:519-30.

76. Moretti EW, Morris RW, Podgoreanu M, Schwinn DA, Newman MF, Bennett E, et al. APOE polymorphism is associated with risk of severe sepsis in surgical patients. Crit Care Med 2005;33:2521-6.

77. Hinrichs C, Kotsch K, Buchwald S, Habicher M, Saak N, Gerlach $\mathrm{H}$, et al. Perioperative gene expression analysis for prediction of postoperative sepsis. Clin Chem 2010;56:613-22.

78. Holweg CT, Weimar W, Uitterlinden AG, Baan CC. Clinical impact of cytokine gene polymorphisms in heart and lung transplantation. J Heart Lung Transplant 2004;23:1017-26.

79. Diatchenko L, Nackley AG, Slade GD, Bhalang $K$, Belfer I, Max MB, et al. Catechol-O-methyltransferase gene polymorphisms are associated with multiple pain-evoking stimuli. Pain 2006;125:216-24.

80. Diatchenko L, Slade GD, Nackley AG, Bhalang K, Sigurdsson A, Belfer I, et al. Genetic basis for individual variations in pain perception and the development of a chronic pain condition. Hum Mol Genet 2005;14:135-43.

81. NackleyAG,ShabalinaSA,TchivilevaIE,SatterfieldK, KorchynskyiO, MakarovSS, etal.Human catechol-O-methyltransferase haplotypes modulate protein expression by altering mRNA secondary structure. Science 2006;314:1930-3.

82. Sadhasivam S, Chidambaran V, Olbrecht VA, Esslinger HR, Zhang K, Zhang X, et al. Genetics of pain perception, COMT and postoperative pain management in children. Pharmacogenomics 2014;15:277-84.

83. Meineke I, Freudenthaler S, Hofmann U, Schaeffeler E, Mikus G, Schwab M, et al. Pharmacokinetic modelling of morphine, morphine-3-glucuronide and morphine-6-glucuronide in plasma and cerebrospinal fluid of neurosurgical patients after short-term infusion of morphine. Br J Clin Pharmacol 2002;54:592-603.

84. Park HJ, Shinn HK, Ryu SH, Lee HS, Park CS, Kang JH. Genetic polymorphisms in the ABCB1 gene and the effects of fentanyl in Koreans. Clin Pharmacol Ther 2007;81:539-46.

85. Kesimci E, Engin AB, Kanbak O, Karahalil B. Association between $A B C B 1$ gene polymorphisms and fentanyl's adverse effects in Turkish patients undergoing spinal anesthesia. Gene 2012;493:273-7.

86. Coulbault L, Beaussier M, Verstuyft C, Weickmans $H$, Dubert L, Trégouet D, et al. Environmental and genetic factors associated with morphine response in the postoperative period. Clin Pharmacol Ther 2006;79:316-24.

87. Sadhasivam S, Chidambaran V, Zhang X, Meller J, Esslinger H, Zhang K, et al. Opioid-induced respiratory depression: ABCB1 transporter pharmacogenetics. Pharmacogenomics J 2015;15:119-26.

88. Huang $\mathrm{P}$, Chen C, Mague SD, Blendy JA, Liu-Chen LY. A common single nucleotide polymorphism A118G of the $\mu$ opioid receptor alters its $\mathrm{N}$-glycosylation and protein stability. Biochem J 2012;441:379-86.

89. Chou WY, Wang CH, Liu PH, Liu CC, Tseng CC, Jawan B. Human opioid receptor A118G polymorphism affects intravenous patient-controlled analgesia morphine consumption after total abdominal hysterectomy. Anesthesiology 2006;105:334-7.
90. Chou WY, Yang LC, Lu HF, Ko JY, Wang CH, Lin SH, et al. Association of mu-opioid receptor gene polymorphism (A118G) with variations in morphine consumption for analgesia after total knee arthroplasty. Acta Anaesthesiol Scand 2006;50:787-92.

91. Sia AT, Lim Y, Lim EC, Goh RW, Law HY, Landau R, et al. A118G single nucleotide polymorphism of human mu-opioid receptor gene influences pain perception and patient-controlled intravenous morphine consumption after intrathecal morphine for postcesarean analgesia. Anesthesiology 2008;109:520-6.

92. Janicki PK, Schuler G, Francis D, Bohr A, Gordin V, Jarzembowski $\mathrm{T}$, et al. A genetic association study of the functional A118G polymorphism of the human mu-opioid receptor gene in patients with acute and chronic pain. Anesth Analg 2006;103:1011-7.

93. Chidambaran V, Mavi J, Esslinger H, Pilipenko V, Martin LJ, Zhang K, et al. Association of OPRM1 A118G variant with risk of morphine-induced respiratory depression following spine fusion in adolescents. Pharmacogenomics J 2015;15:255-62.

94. Walter C, Lötsch J. Meta-analysis of the relevance of the OPRM1 118A $>\mathrm{G}$ genetic variant for pain treatment. Pain 2009;146:270-5.

95. Bisogno T, Maccarrone M. Latest advances in the discovery of fatty acid amide hydrolase inhibitors. Expert Opin Drug Discov 2013;8:509-22.

96. Fichna J, Salaga M, Stuart J, Saur D, Sobczak M, Zatorski H, et al. Selective inhibition of FAAH produces antidiarrheal and antinociceptive effect mediated by endocannabinoids and cannabinoid-like fatty acid amides. Neurogastroenterol Motil 2014;26:470-81.

97. Sadhasivam S, Zhang X, Chidambaran V, Mavi J, Pilipenko V, Mersha TB, et al. Novel associations between FAAH genetic variants and postoperative central opioid-related adverse effects. Pharmacogenomics J 2015; 15:436-42.

98. Ratain MJ. Personalized medicine: Building the GPS to take us there. Clin Pharmacol Ther 2007;81:321-2.

99. Lötsch J, Geisslinger G. Current evidence for a genetic modulation of the response to analgesics. Pain 2006;121:1-5.

100. Argoff CE. Clinical implications of opioid pharmacogenetics. Clin J Pain 2010;26 Suppl 10:S16-20.

101. Biesiada J, Chidambaran V, Wagner M, Zhang X, Martin LJ, Meller J, et al. Genetic risk signatures of opioid-induced respiratory depression following pediatric tonsillectomy. Pharmacogenomics 2014;15:1749-62.

102. Kannry JL, Williams MS. Integration of genomics into the electronic health record: Mapping terra incognita. Genet Med 2013;15:757-60.

103. Gottesman O, Kuivaniemi H, Tromp G, Faucett WA, Li R, Manolio TA, et al. The Electronic Medical Records and Genomics (eMERGE) Network: Past, present, and future. Genet Med 2013;15:761-71.

104. Pasche B, Absher D. Whole-genome sequencing: A step closer to personalized medicine. JAMA 2011;305:1596-7.

105. Stenson PD, Mort M, Ball EV, Howells K, Phillips AD, Thomas NS, et al. The human gene mutation database: 2008 update. Genome Med 2009;1:13.

106. Bale S, Devisscher M, Van Criekinge W, Rehm HL, Decouttere F, Nussbaum R, etal.MutaDATABASE: A centralized and standardized DNA variation database. Nat Biotechnol 2011;29:117-8.

107. Houdayer C, Dehainault C, Mattler C, Michaux D, Caux-Moncoutier V, Pagès-Berhouet $S$, et al. Evaluation of in silico splice tools for decision-making in molecular diagnosis. Hum Mutat 2008;29:975-82.

108. Adzhubei IA, Schmidt S, Peshkin L, Ramensky VE, Gerasimova A, Bork $\mathrm{P}$, et al. A method and server for predicting damaging missense mutations. Nat Methods 2010;7:248-9.

109. Katsanis SH, Katsanis N. Molecular genetic testing and the future of clinical genomics. Nat Rev Genet 2013;14:415-26. 